\title{
BADLAND MORPHOLOGY AND EVOLUTION: INTERPRETATION USING A SIMULATION MODEL
}

\author{
ALAN D. HOWARD \\ Department of Environmental Sciences, University of Virginia, Charlottesville, VA 22903, USA
}

Received 26 July 1996; Revised 27 September 1996; Accepted 27 September 1996

\begin{abstract}
A drainage basin simulation model is used to interpret the morphometry and historical evolution of Mancos Shale badlands in Utah. High relief slopes in these badlands feature narrow divides and linear profiles due to threshold mass-wasting. Threshold slopes become longer in proportion to erosion rate, implying lower drainage density and higher relief. By contrast, in slowly eroding areas of low relief, both model results and observations indicate that drainage density increases with relief, suggesting control by critical shear stress. Field relationships and simulation modelling indicate that the badlands have resulted from rapid downcutting of the master drainage below an Early Wisconsin terrace to the present river level, followed by base level stability. As a result, Early Wisconsin alluvial surfaces on the shale have been dissected up to $62 \mathrm{~m}$ into steep badlands, and a Holocene alluvial surface is gradually replacing the badland slopes which are eroding by parallel retreat. (C) 1997 by John Wiley \& Sons, Ltd.
\end{abstract}

Earth surf. processes landf., 22, 211-227 (1997)

No. of figures: $11 \quad$ No. of tables: 0 No. of refs: 35

KEY WORDS badland; mass wasting; morphometry; fluvial; Quaternary; simulation

\section{INTRODUCTION}

The badlands developed in the Cretaceous age Mancos Shale near Caineville, Utah, are among the most spectacular in the United States due to their areal extent, steep slopes, high relief, absence of vegetation, knifeedge divides, and lithologic uniformity (Figure 1). Both the erosional history and the relationship between process and form are reasonably well understood for these badlands as a result of several studies starting from Gilbert's classic treatise (Gilbert, 1880; Hunt, 1953; Howard, 1970, 1986, 1994a; Anderson et al., 1996). This affords the opportunity to utilize a quantitative model of drainage basin evolution (Howard, 1994b) to help understand the evolution of these badlands. In particular, the model will be used to evaluate qualitative interpretations by Howard (1970, 1994a) concerning the influence of areal variations of erosion rate upon slope form and drainage density and the history of base level lowering and landform development during the late Quaternary. The model and its predictions regarding drainage basin morphology are outlined below, followed by its application to interpreting landform morphology and evolution in the Caineville area badlands.

\section{THE DRAINAGE BASIN MODEL}

The drainage basin model of Howard (1994b) combines diffusive (mass-wasting and rainsplash) plus advective (fluvial erosional) processes. Several one- and two-dimensional advection-dispersion landscape models have been developed (e.g. Ahnert, 1976, 1987; Hirano, 1975; Kirkby, 1971, 1986; Willgoose et al., 1991a,b), but the present model differs from most of these by assuming that headwater channels are detachment-limited (although Ahnert $(1976,1987)$ allows the possibility of similar 'suspended-load' runoff erosion). 


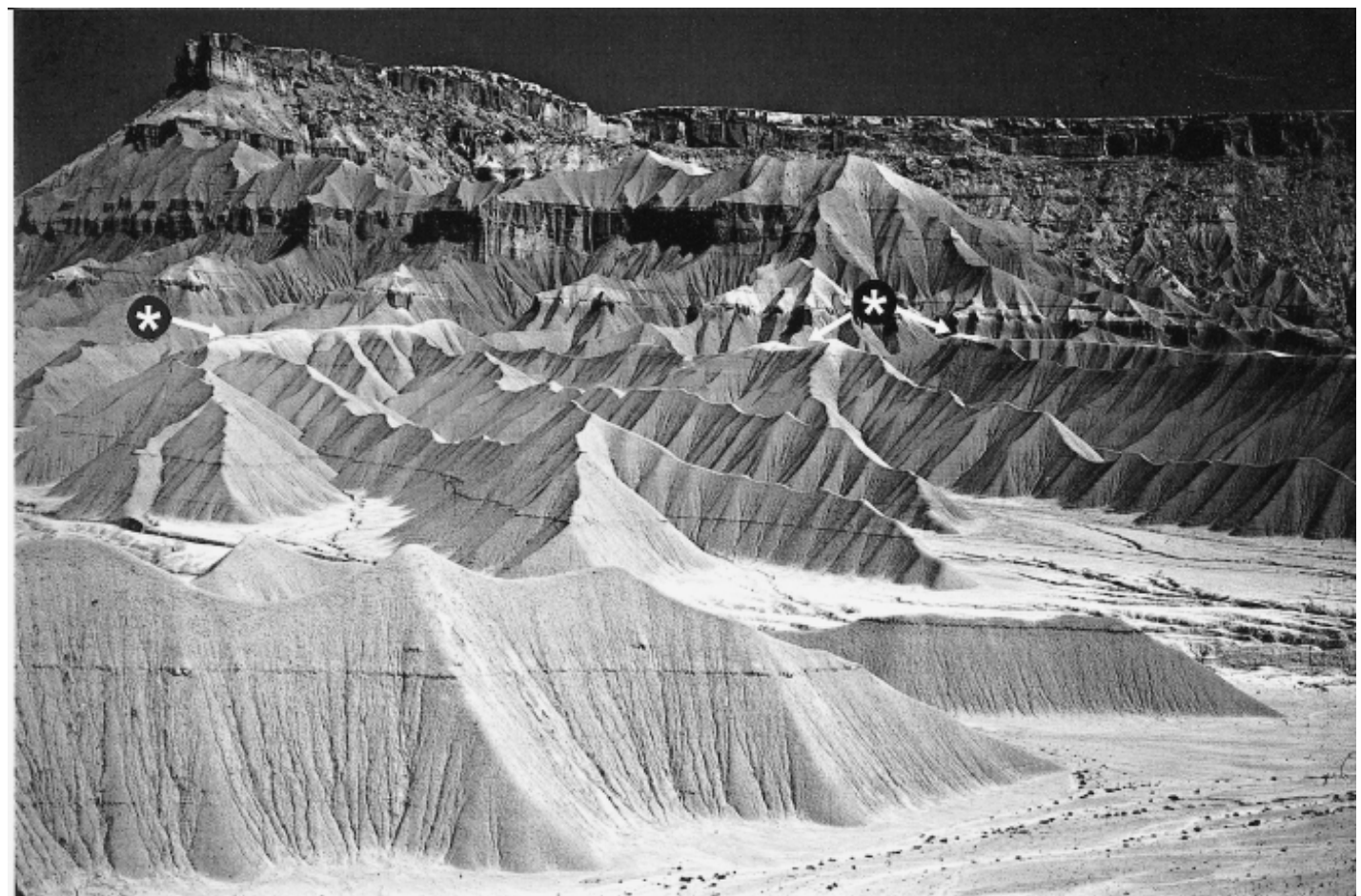

Figure 1. Badlands in Mancos Shale near Caineville, Utah. The top of North Caineville Mesa in the background is $360 \mathrm{~m}$ above the alluvial surface in the middle distance, and is capped by the $60 \mathrm{~m}$ thick Emery Sandstone. Note the sharp-crested, straight-sloped badlands in Mancos Shale in the middle distance which arise abruptly $30-50 \mathrm{~m}$ above the Holocene alluvial surface. Level ridge crests marked by an asterisk are remnants of the early Wisconsin pediment.

Potential erosion or deposition due to diffusive processes,

$$
\left.\frac{\delta z}{\delta t}\right|_{\mathrm{m}}
$$

is given by the spatial divergence of the vector flux of regolith movement $q_{m}$ :

$$
\left.\frac{\delta z}{\delta t}\right|_{\mathrm{m}}=-\nabla \cdot q_{\mathrm{m}}
$$

The rate of movement is expressed by two additive terms, one for creep and/or rainsplash diffusion and one for near-failure conditions:

$$
q_{\mathrm{m}}=\left[K_{\mathrm{s}} \mathscr{G}(S)+K_{\mathrm{f}}\left[\frac{1}{\left(1-K_{\mathrm{x}}|\mathrm{S}|^{\mathrm{a}}\right)}-1\right] s\right.
$$

where $\mathrm{G}(S)$ is an increasing function of slope gradient, $s$ is the unit vector in the direction of $S$, and $|S|$ is the absolute value of local slope gradient. The constants $K_{\mathrm{s}}, K_{\mathrm{x}}, K_{\mathrm{f}}$, and the exponent $\alpha$ are assumed to be spatially and temporally invariant. The diffusivities $K_{\mathrm{s}}$ and $K_{\mathrm{f}}$ depend jointly upon regolith properties and climatic forcing. The model here assumes that G $(S)$ is simply the slope gradient, $S$. The bracketed term in Equation 2 models near-failure conditions on slopes such that mass movement rates increase without limit as gradient approaches a threshold value, $S_{\mathrm{t}}=\left(1 / K_{\mathrm{x}}\right)^{1 / \mathrm{a}}$.

Fluvial erosion is advective, and consists of two processes: erosion is detachment-limited in steep channels flowing on bedrock or regolith in which the bedload sediment flux is less than a capacity load; in lower gradient 
alluvial channels erosion is transport-limited. The erosion rate due to detachment,

$$
\left.\frac{\delta z}{\delta t}\right|_{\mathrm{c}}
$$

is assumed to be proportional to the shear stress, $\tau$, exerted on the bed and banks by a dominant discharge:

$$
\left.\frac{\delta z}{\delta t}\right|_{\mathrm{c}}=-K_{t}\left(\tau-\tau_{\mathrm{c}}\right)
$$

where $\tau_{c}$ is a critical shear stress.

Shear stress can be related to channel gradient and drainage area through the use of equations of steady, uniform flow as discussed by Howard (1994b), allowing the erosion rate to be re-expressed as a function of contributing area, $A$, and local channel gradient, $S$ :

$$
\left.\frac{\delta z}{\delta t}\right|_{\mathrm{c}}=-K_{t}\left(K_{\mathrm{z}} A^{\mathrm{g}} S^{\mathrm{h}}-\tau_{\mathrm{c}}\right)
$$

where $K_{\mathrm{t}}$ and $K_{\mathrm{z}}$ are assumed to be temporally and areally invariant, and the exponents $g$ and $h$ have values of about 0.3 and $0 \cdot 7$, respectively. The detachment rate could alternatively be assumed to be proportional to other measures of flow strength, such as stream power, which has the effect of changing the exponents $g$ and $h$ to near unity in Equation 4 and replacing $\tau_{\mathrm{c}}$ with a critical stream power.

In alluvial channels the potential rate of erosion (or deposition) equals the spatial divergence of the volumetric unit bed sediment transport rate, $q_{\mathrm{sb}}$ :

$$
\left.\frac{\delta z}{\delta t}\right|_{\mathrm{c}}=-\nabla \cdot q_{\mathrm{sb}}
$$

Many bedload and total load sediment transport equations can be expressed as a functional relationship between the two dimensionless parameters $\phi$ and $1 / \Psi$ :

$$
\phi=K_{\mathrm{e}}\left\{\frac{1}{\Psi}-\frac{1}{\Psi_{\mathrm{c}}}\right\}^{\mathrm{p}}
$$

where

$$
\phi=\frac{q_{s b}}{\omega d(1-\mu)} \text { and } \frac{1}{\Psi}=\frac{\tau}{\left(\gamma_{\mathrm{s}}-\gamma\right) d}
$$

In these equations, $q_{\mathrm{sb}}$ is bed sediment transport rate in bulk volume of sediment per unit time per unit channel width, $\omega$ is the fall velocity of the sediment grains, $d$ is the sediment grain size, $\mu$ is alluvium porosity, and $\gamma_{s}$ is the unit weight of sediment grains. As discussed by Howard (1994b), this equation can be recast into a relationship between total bed sediment discharge, $q_{\mathrm{sb}}$, drainage area, and gradient:

$$
q_{\mathrm{sb}}=K_{\mathrm{q}} A^{\mathrm{r}}\left[K_{\mathrm{v}} A^{\mathrm{s}} S^{t}-1 / \Psi_{\mathrm{c}}\right]^{\mathrm{p}}
$$




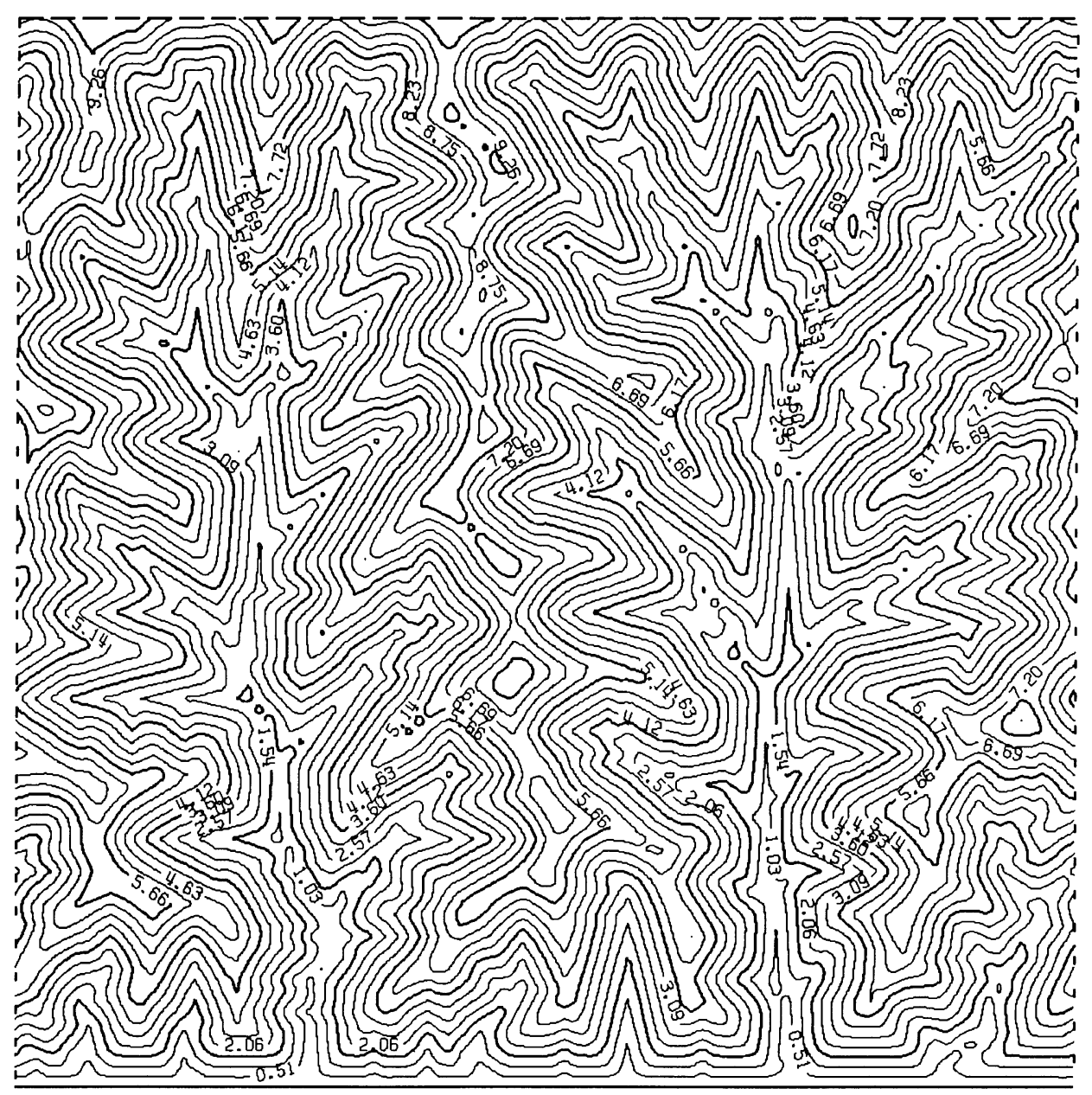

Figure 2. A simulated steady-state drainage basin with maximum slope angles close to the threshold of stability and linear slope profiles. Simulation parameters are $K_{\mathrm{s}}=0 \cdot 1, S_{\mathrm{t}}=0 \cdot 6, K_{\mathrm{t}} K_{\mathrm{z}}=1 \cdot 0, X=500, \tau_{\mathrm{c}}=0, g=0 \cdot 3, h=0 \cdot 7, k_{\mathrm{f}}=0 \cdot 5, a=3$; erosion rate, $E=-1 \cdot 0$. The simulation matrix size is $100 \times 100$ cells of unity size. Contour interval $0 \cdot 51$, maximum elevation $10 \cdot 8$.

where $K_{\mathrm{q}}$ and $K_{\mathrm{v}}$ are constants, and the exponents $p, r, s$ and $t$ have values of about 3.0, 0.5, $0 \cdot 3$ and $0 \cdot 7$, respectively, for transport in sand-bed channels.

The simulations assume that the amount of erosion accomplished during an individual erosional event is small compared to the scale of the landform, so that the above processes can be approximated as being continuous. The actual erosion (or deposition) occurring at a point,

$$
\frac{\delta z}{\delta t}
$$

is a weighted sum of the potential mass-wasting and fluvial erosion rates, as discussed in Howard (1994b). Regolith delivered by mass-wasting into channels is assumed to be more erodible than the bedrock by a factor $\mathrm{X}$. Runoff yield is assumed to be areally uniform, which is reasonable for these uniform, nearly impermeable badlands.

An example of a steady-state simulation generated by a constant rate of lowering of the lower boundary is shown in Figure 2. In this and the other simulations, the lower, level boundary is the base level control, the lateral boundaries are periodic in that water and sediment crossing the boundary re-enter on the opposite side, and the upper boundary is no-flux. Also, all channels are assumed to be bedrock with erosion rate governed by 
Equation 4. Initial conditions are a flat surface with a slight fractal perturbation. In this simulation the second, threshold term in Equation 2 dominates over the linear diffusion term except at the immediate divides, producing a nearly linear slope profile. Simulations in which linear creep erosion predominates produce broadly convex divides with a short concave zone at the slope base (see Howard (1994b) for examples.

\section{Model predictions of drainage density, relief and slope form}

Because of the effects of convergence and divergence in areal landscape modelling, the governing equations are not readily solved to infer how the scale of the landscape, and in particular relief and drainage density, vary with model parameters. The difficulty is compounded because the drainage density is not defined a priori in the simulation model; rather, valley heads are defined operationally by a critical value of topographic convergence, that is, the valley network occurs where

$$
\frac{\nabla^{2} z}{\bar{S}} \geq D_{\mathrm{c}}
$$

where $\mathrm{z}$ is elevation $\bar{S}$ is the average slope gradient, and $D_{\mathrm{c}}$ is a critical value of the normalized divergence. The general controls on drainage density, however, can be examined with a simplified model assuming a profile (one-dimensional (1-D)) landscape. A number of theoretical studies have investigated factors controlling drainage density, but most have considered either transport-limited sediment movement alone (Smith and Bretherton, 1972) or a combination of diffusional and transport-limited erosion (e.g. Kirkby, 1980, 1994; Willgoose, 1991). Detachment-limited water erosion has not been considered, except as a transport threshold (e.g. Willgoose, 1991; Kirkby, 1994). The effects of overall erosion rate have not been explicitly studied.

In the simplest version of the model, the threshold term in Equation 2 is unimportant, so that creep rate depends linearly on slope gradient (as assumed by Culling (1960, 1963), Kirkby (1971), and many others)), and the rate of erosion by creep is:

$$
\left.\overline{\delta z}\right|_{\mathrm{m}}=K_{\mathrm{s}} \frac{\delta^{2} z}{\delta x^{2}}
$$

where $x$ is the horizontal distance from the divide. Assuming that the landscape is in steady state so that the erosion rate due to creep,

$$
\left.\overline{\delta z}\right|_{\mathrm{m}}
$$

is a spatially uniform constant $E_{\mathrm{s}}$, this equation can be integrated to give (e.g. Kirkby, 1971, 1980):

$$
S=\frac{E_{\mathrm{s}} x}{K_{\mathrm{s}}}
$$

In steep terrain, erosion rates may be sufficiently high that slope gradient is generally close to failure conditions (dominance by the threshold term in Equation 2). The slope gradient then becomes essentially independent of erosion rate or location on the slope, such that $S=S_{\mathrm{t}}$, where $S_{\mathrm{t}}$ is the threshold gradient.

Assuming that the headwater channels are detachment-limited, and that the landscape is in steady state with a rate of fluvial erosion $E_{\mathrm{c}}$, then Equation 4 can be solved for $S$ by replacing the area term by distance from the divide, $x$ :

$$
S=\left[\left\{\frac{1}{K_{\mathrm{z}}}\right\}\left\{\frac{E_{\mathrm{c}}}{K_{\mathrm{t}}}+\tau_{\mathrm{c}}\right\}\right]^{1 / \mathrm{h}} x^{-\mathrm{g} / \mathrm{h}}
$$


These equations can be combined to predict the location $x_{0}$ on the slope where slope and channel processes are equally important, assuming that the fluvial and slope erosion rates are equal and their sum is the overall erosion rate, $E$, and that the two slope gradients are also equal. There are two end member cases:

$$
x_{0}=\left[\frac{2 K_{\mathrm{s}}}{E}\right]^{(\mathrm{h} /(\mathrm{h}+\mathrm{g}))}\left[\left\{\frac{1}{K_{\mathrm{z}}}\right\}\left\{\frac{E}{2 K_{\mathrm{t}}}+\tau_{\mathrm{c}}\right\}\right]^{(1 /(\mathrm{h}+\mathrm{g}))}
$$

for slopes with linear creep erosion, and for threshold slopes:

$$
x_{0}=S_{\mathrm{t}}^{-\mathrm{h} / \mathrm{g}}\left[\left\{\frac{1}{K_{\mathrm{z}}}\right\}\left\{\frac{E}{2 K_{\mathrm{t}}}+\tau_{\mathrm{c}}\right\}\right]^{1 / \mathrm{g}} \quad \text { (Case II) }
$$

Each of these two cases in turn shows two end members, the first (Case A) where the threshold for fluvial erosion is negligible, that is,

$$
\frac{E}{2 K_{\mathrm{t}}}>\tau_{\mathrm{c}}
$$

and the second (Case B) where the channel system gradients are very close to their threshold value.

The drainage density should be inversely related to $x_{0}$ (which is equivalent to Schumm's (1956) 'constant of channel maintenance'). Case IA, with linear creep erosion and no threshold for fluvial erosion, shows a slight inverse dependency of drainage density on erosion rate (Figure 3A). Case IB, with threshold channel erosion, predicts that drainage density should increase with higher erosion rates (Figure $3 \mathrm{~A}$ ). By contrast, if channels are not close to threshold conditions but slopes are at their threshold gradient (Case IIA, Figure 3A), drainage density decreases markedly as erosion rates increase, corresponding to longer slopes and higher relief for higher erosion rates. If the channels as well as the slopes are near threshold values (Case IIB, Figure 3A), varying erosion rates do not affect drainage density. Variation of the assumed exponents $g$ and $h$ have little effect on
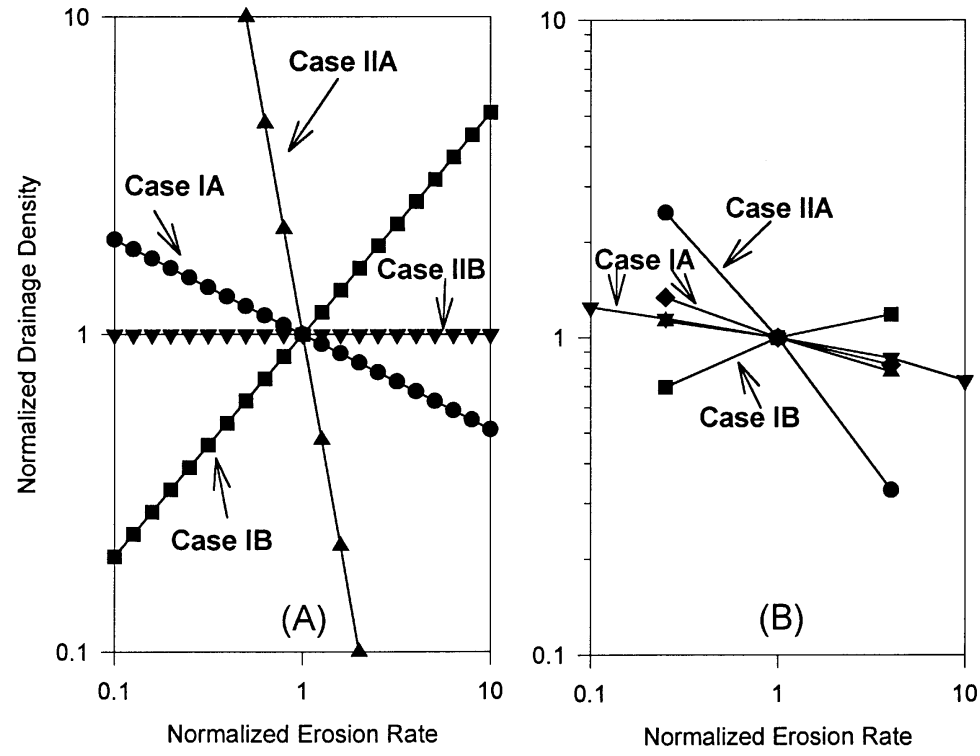

Figure 3. Dependence of drainage density on erosion rate in steady-state topography. (A) Results of theoretical one-dimensional model (results are scaled to unity drainage density with unity erosion rate); (B) results of two-dimensional simulation model. See text for explanation of cases. 


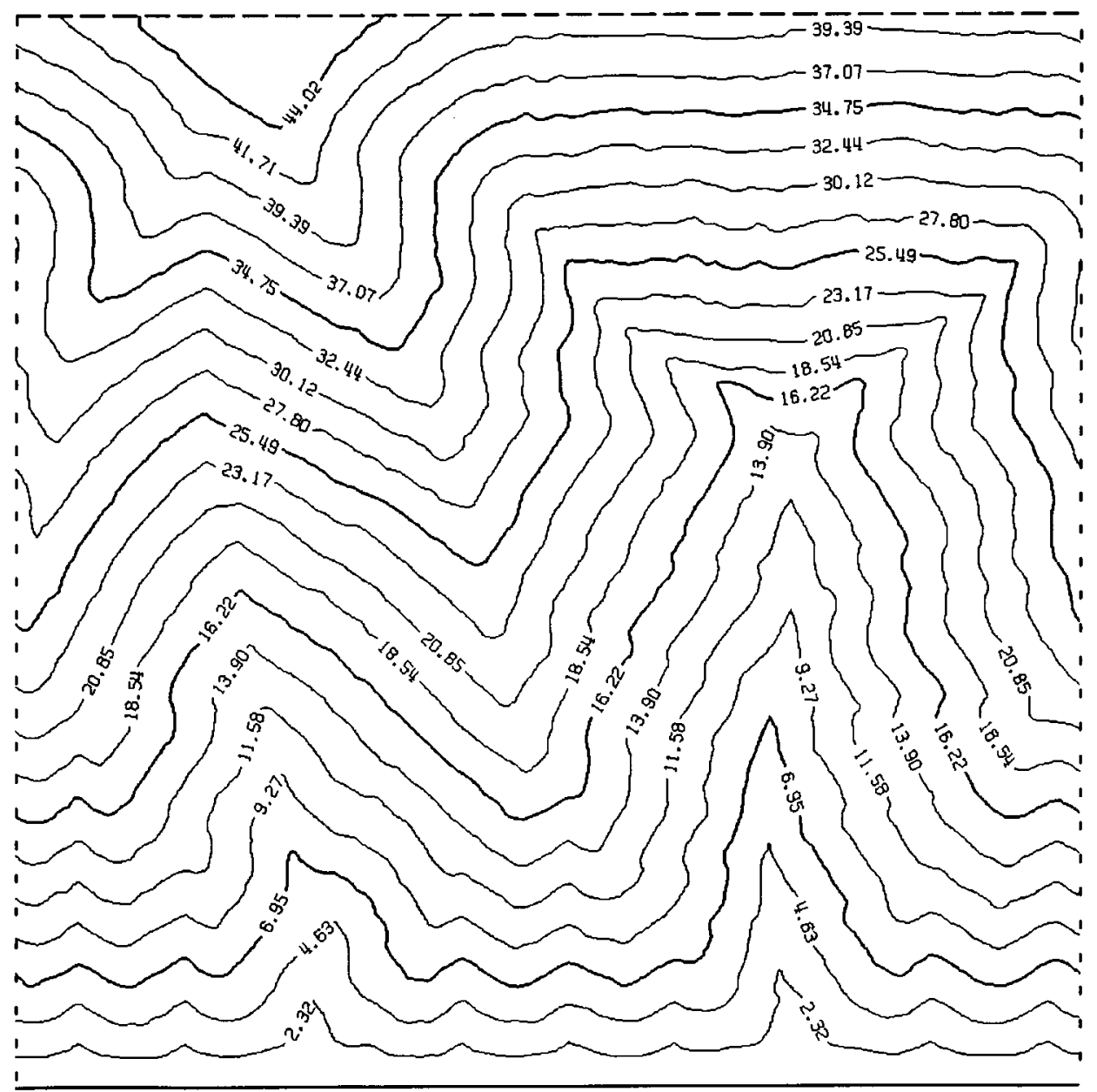

Figure 4. Simulated steady-state topography with simulation parameters as in Figure 2 except that erosion rate, $E=4 \cdot 0$. Contour interval $2 \cdot 32$, maximum elevation $48 \cdot 7$.

these relationships, except that the inverse relationship in Case IA changes to no dependency for the stream power case of $g=1$ and $h=1$ (of course, the assumed exponents do have a strong effect upon stream profile convexity and the transient response to changes in incision rate).

Drainage density defined by this 1-D theory have been compared with results of the two-dimensional (2-D) simulation model by conducting steady-state simulations for a wide range of downcutting rates and for parameters consistent with Cases IA, IB and IIA, above (Figure 3B). In these simulations the critical normalized convergence, $D_{c}$, was assumed to equal $1 \cdot 6$, a value which provides a valley network similar to that which would be defined by the contour crenulation method (Howard, 1994b). The theory and simulations show a similar pattern of dependency of drainage density upon erosion rates (cf. Figures 3A and 3B). Very similar dependencies of drainage densities upon erosion rate occur in the case of combined diffusional and transportlimited fluvial erosion (Equation 8), except that Case IA shows a slight positive rather than inverse relationship.

In all of the above cases, overall relief increases as erosion rate increases (relief, $R \sim S x_{0}$ ), so that in rock of uniform erosional properties and steady-state topography, relief can be used as a surrogate for erosion rate. Figure 4 shows a low drainage density, high relief steady-state landscape with threshold slopes developed with the same simulation parameters as in Figure 2 but with a downcutting rate four times greater. By contrast, low relief, high drainage density landscapes are developed for downcutting rates smaller than that in Figure 2. 


\section{THE MANCOS SHALE BADLANDS}

In the desert area at the foot of the Henry Mountains, Utah, along the Fremont River, a series of Jurassic and Cretaceous shales and sandstones are exposed as a series of cuestas capped by the sandstones and fronted by badlands and alluvial surfaces (pediments) developed in the shales. In particular, the scarps in the Cretaceous Emery Sandstone are underlain by the $600 \mathrm{~m}$ thick marine Mancos Shale (Figure 1) exhibiting a remarkably uniform lithology. As a result of rainshadow effects from higher mountains on the Colorado Plateau, the climate is arid despite an elevation of about $1500 \mathrm{~m}$ above mean sea level, with about $125 \mathrm{~mm}$ of annual precipitation, most of which occurs as summer thunderstorms. As a result, the badlands are essentially devoid of vegetation.

\section{Erosional processes, drainage density and slope form}

Despite the absence of a protective vegetation cover and the rapid erosion, the Mancos Shale badlands have a thin regolith except on a few weathering-limited slopes with gradients greater than about $50^{\circ}$. The top 3 to $5 \mathrm{~cm}$ is a compact surface layer exhibiting polygonal desiccation cracks when dry. Underlying this is a looser granular sublayer of partially weathered shale shards grading gradually to dense, unweathered shale at a depth of 10 to $25 \mathrm{~cm}$. When unweathered Mancos Shale is saturated with water, it decomposes within a few tens of hours into loose flaky chips with a modest net swelling ( $<25$ per cent volume increase), yielding a yellowish liquor of dissolved salts (mostly sodium and calcium sulphates (Laronne, 1981, 1982)). If these salts are not leached, further disintegration of the shale is inhibited. Thin whitish crusts of salts are common, where they have accumulated during evaporation following storms.

In areas of high relief and rapid erosion, the Mancos badlands have a nearly linear profile with narrow, rounded divides, which range in width from less than $0.5 \mathrm{~m}$ in high relief badlands to 1 to $2 \mathrm{~m}$ in low relief areas (Figure 1). Because of the very thin regolith on these narrow divides and a shale-chip surface armouring, Howard (1970) and Moseley (1973) attributed the divide rounding to rainsplash rather than creep. This process is effective on narrow divides even at low gradient, because the maximum splash distance is greater than the divide width. However, in areas of low relief, the regolith is thicker and divides are more rounded, so that creep may be a dominant process.

Virtually all high relief badland slopes in the Mancos Shale have slope angles ranging between $36^{\circ}$ and $46^{\circ}$. These are $3^{\circ}$ to $10^{\circ}$ steeper than the angle of respose of dry detritus weathered from the formations, owing to cohesiveness of the surface layer. Consequently, such steep slopes are on the verge of failing by flowage and slipping. Whole sections of hillside appear to slip short distances during rainstorms producing tension cracks arranged in waves, suggesting differential movement, and, rarely, extensive shallow slumping. Tension cracks are more numerous and wider the steeper the gradient, particularly on slopes undercut by meandering washes.

The upper portions of badland slopes are relatively smooth, indicating a dominance by diffusive masswasting and rainsplash processes. However, the lower portions are generally dissected by ephemeral rills, suggesting a handover to a dominance by wash erosion (Figure 1). Further description of the erosional processes and morphology of the Caineville badlands can be found in Howard (1970, 1994a).

Nearly linear lower slopes on regolith-mantled, high relief badlands would be expected if threshold masswasting determines slope form. Close to the divide, where creep and rainsplash fluxes are small and gradients are low, creep velocity is probably porportional to the sine of the slope angle, so that gradients increase rapidly downslope. As the flux of mass-wasting debris increases downslope, equivalent rates of erosion may require gradients approaching the limiting slope angle where slippage or flowage becomes important, and the incremental addition of weathered material along the slope can be accommodated by a very slight increase in gradient; thus a nearly straight profile results. These are the threshold slopes of Carson (1971) and Carson and Petley (1970), except that they can be modelled by a rapid but continuous increase in mass-wasting rate as the limiting angle is approached, rather than by an abrupt threshold. A similar approach was used by Kirkby (1984, 1985). Figure 2 is a steady-state simulation in which threshold mass-wasting predominates. The linear slopes and narrow divides resemble the Caineville badlands (Figure 1).

Areal variations in badland slope steepness, slope length and relief provide indirect evidence for threshold processes. Average hillslope gradients in badlands of the Mancos Formation show little variation with slope length except for very short slopes (Figure 5). However, the drainage density exhibits a complicated 


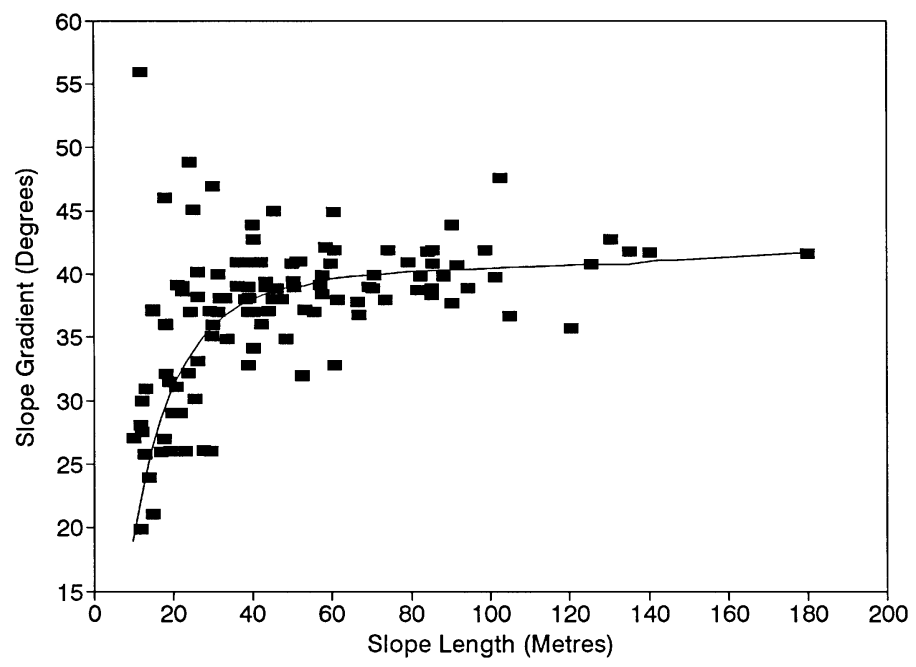

Figure 5. Plot of hillslope gradient versus slope length in Mancos Shale badlands. The short slopes with very high gradients occur on undercut banks along meandering washes.

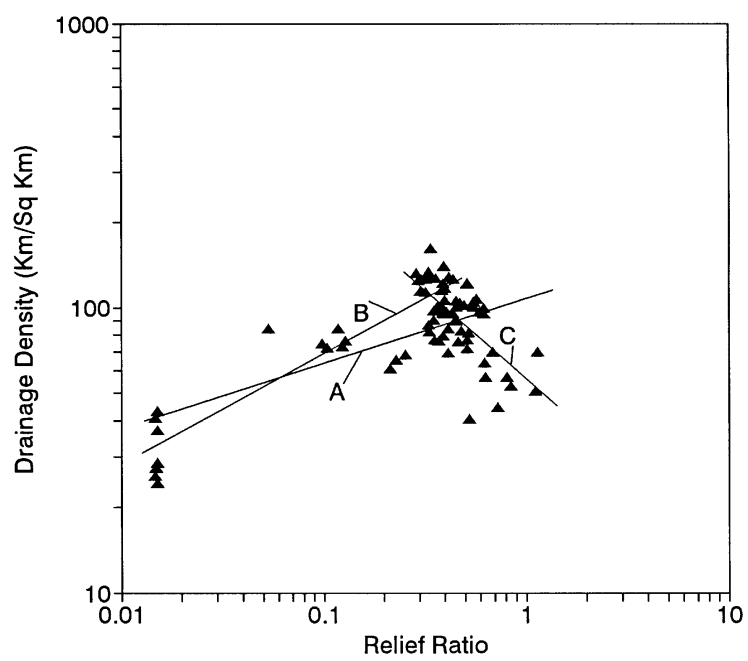

Figure 6. Drainage density versus relief ratio for badland areas on Mancos Shale. Measurements made on areal photographs with a scale of approximately 1:12000. Relief ratio determined by inscribing a $150 \mathrm{~m}$ diameter circle around a badland divide and measuring the maximum relief photogrammetrically and dividing by $75 \mathrm{~m}$. Drainage density is defined as total length of all hollows and valleys visible on the photograph in the circle divided by the area of the circle. Ephemeral rills lacking defining ridge lines are not included. Regression

lines are A for all points, B for values of relief ratio less than $0 \cdot 35$, and $\mathrm{C}$ for values greater for $0 \cdot 2$. All are statistically significant.

relationship to relief ratio, generally increasing with relief ratio up to a value of about $0 \cdot 5$, but decreasing in very high relief badlands (Figure 6). The locations with low relief ratios occur in slowly eroding areas protected by distance or resistant beds from recent incision of the nearby Fremont River, whereas the high relief area border the river or are exposed on the escarpment ramparts. The relatively low drainage density of areas with very high relief ratio may be explained by the onset of slipping on steep slopes, such that large increases of basal slope erosion should be accompanied by only a slight increase in gradient. But the small increase in slope angle increases the efficiency of erosion on the slope relative to the channel, so that the critical drainage area necessary to support a channel increases, with a resulting decrease in drainage density. This is illustrated in the steady-state simulations in Figures 2 and 4, in which increased erosion rate is accompanied by decreasing drainage density and lengthened slope profiles and an inverse relationship between relief and drainage density for threshold slopes (Equation 14 and Figure 3). 
By contrast, in areas of low overall relief in the Caineville badlands, relief and drainage density are positively correlated (Figure 6). Slope profiles are convex, suggesting that linear diffusional mass-wasting predominates, at least near divides, and Equation 13 and Figure 3 indicate that greater erosion rate (and greater relief) are associated with higher drainage density if the threshold for fluvial erosion governs channel heads. Therefore, the transition from a positive to an inverse relationship between drainage density and relief observed in the Caineville badlands (Figure 6) is attributed to a change from diffusion mass-wasting and threshold fluvial control (corresponding to Case IB) to threshold-dominated (Case IIA) mass-wasting (Figure 3). Drainage density in experimental channel networks developed in a rainfall simulator increased with relief (Table 2.2 in Schumm et al., 1987), also suggesting control by rainsplash diffusion and threshold fluvial erosion (Case IB).

\section{Interpretation of erosional history}

The rapid erosion of exposed shale means that badlands occur only where high relief has been created recently. In the Henry Mountains area this has occurred either through erosional removal of a protective caprock or through rapid master stream downcutting. The ramparts of sandstone cuestas feature local badlands in sub-caprock shales, and more extensive badlands occur where buttes have been recently denuded of their caprock. However, the badlands on cuesta ramparts are well developed only during relatively arid epochs (such as the present) when mass-wasting of caprocks is relatively quiescent (Howard and Selby, 1994).

Reconstructing erosional history. The master stream is the Dirty Devil-Fremont River system, which during the Quaternary has had a history of alternating stability or slight aggradation during pluvial epochs with rapid downcutting, followed by stability at the close of non-pluvial epochs (Howard, 1970, 1986). During the pluvial epochs, large quantities of gravel and sand were carried through the Fremont River from partially glaciated high plateaus to the west, depositing strath terraces $3-5 \mathrm{~m}$ thick. During the pluvials the stable base-level coupled with physical weathering and mass-wasting of the sandstone cuestas encouraged development of extensive talus slopes on the ramparts of the escarpments coupled with sandstone gravel-veneered alluvial surfaces mantling the shales. Thus badlands were rare during pluvial epochs, probably occurring only locally on scarp ramparts or caprock-stripped buttes. The dissection of the most recent pluvial river terraces and alluvial surfaces underlain by Mancos Shale has created the spectacular badland landscape near Caineville, Utah (Figures 1 and 7).

A flight of terraces occurs along the Fremont River. The lowest extensive terrace occurs about $62 \mathrm{~m}$ above the current river level (terrace 4A of Howard (1970) and FR2 of Anderson et al. (1996), with one or two less well developed lower terraces and remnants of formerly extensive higher terraces at about 75 and $120 \mathrm{~m}$ above river level. The $62 \mathrm{~m}$ terrace was correlated by Howard (1970) with glacial deposits on nearby Thousand Lake Mountain, identified as Bull Lake age by Flint and Denny (1958) and Smith et al. (1963). Gravel-veneered alluvial surface remnants are common in the badlands area (Figures 1 and 7), and all of these project downstream to the $62 \mathrm{~m}$ terrace. This suggests that the scattered terrace remnants below the $62 \mathrm{~m}$ terrace (4B of Howard (1970) and FR1 of Anderson et al. (1996) correspond either to unpaired strath terraces or to minor periods of alluviation along the Fremont River which had little effect on the evolution of badland morphology. The $62 \mathrm{~m}$ terrace has been dated using ${ }^{10} \mathrm{Be}$ and ${ }^{26} \mathrm{AI}$ cosmogenic isotopes at $\sim 71 \mathrm{ka}$ (Anderson et al., 1996), suggesting a correlation with oxygen isotope stage 4 of Early Wisconsin age (Morrison, 1991). The highest terrace remnants in the Caineville area are at about $120 \mathrm{~m}$ above current river level and have been dated at $\sim 179 \mathrm{ka}$ (R. S. Anderson, personal communication), suggesting a long-term average erosion rate of about $700 \mathrm{~mm} \mathrm{ka}^{-1}$ along this portion of the Fremont River.

Howard (1970) suggested that the Fremont River downcut about $62 \mathrm{~m}$ shortly after the close of the Bull Lake pluvial, followed by stability at about its present level. As a result, a wave of dissection has moved headward towards the sandstone cuestas to which the alluvial surfaces were graded, producing a sequence of landforms from scattered Bull Lake alluvial surface remnants near the scarps (remaining primarily where the capping gravels were thickest), through a zone of high relief $(50$ to $60 \mathrm{~m}$ ) badlands, to modern alluvial surfaces near the master drainage where the badlands have been completely eroded (Figures 1 and 7). Shale areas that are either remote from the master drainage or have been protected from stream downcutting by downstream sandstone exposures are either undissected Bull Lake alluvial surfaces or very low relief badlands. The interpretation of a rapid downcutting from the $62 \mathrm{~m}$ terrace level followed by stability at about the present elevation of the Fremont 


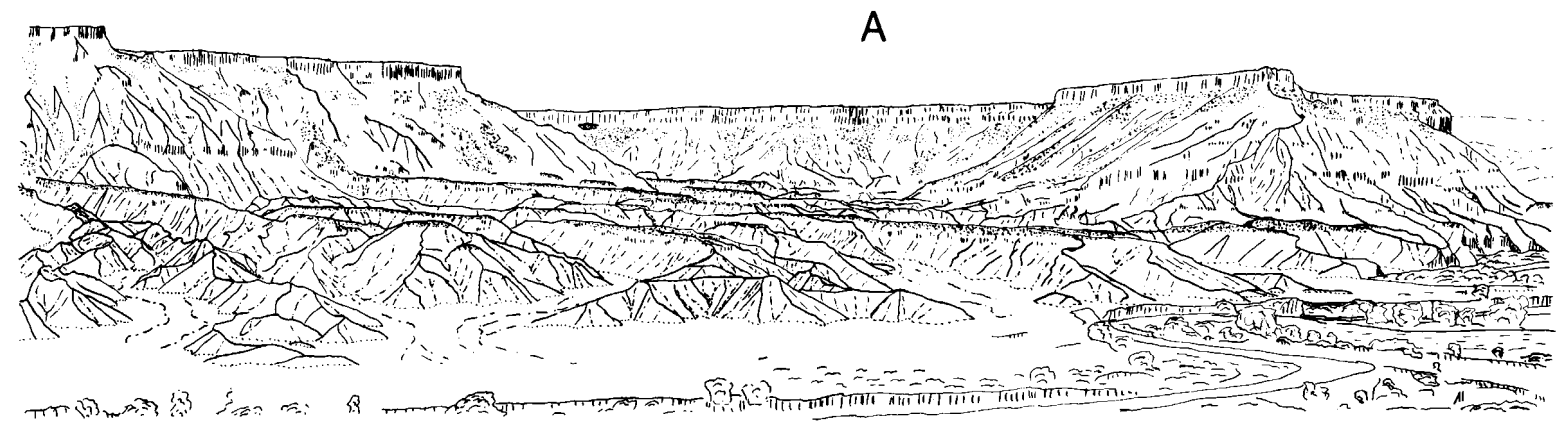

B

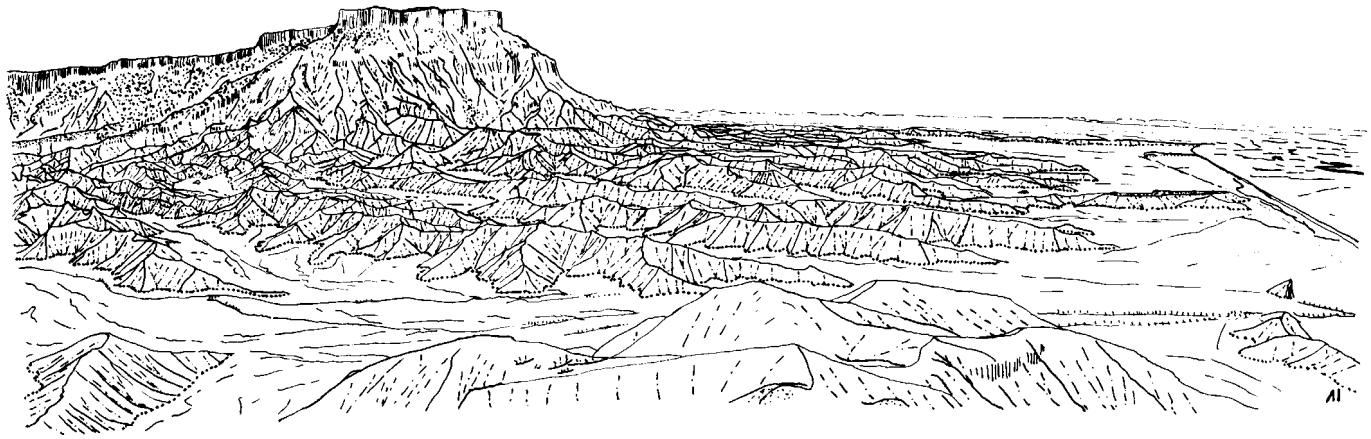

Figure 7. Panoramic views of the Caineville badlands, showing the relationships between the Bull Lake alluvial surface, badlands and Holocene alluvial surface. (A) View from a pre-Wisconsin terrace southward across the Fremont River into a deep re-entrant in South Caineville Mesa. Gravel beneath the dissected Bull Lake alluvial surfaces is stippled, as is debris on escarpment ramparts derived from caprock wasting. Dividers are shown by solid line, rills and washes by dash-dot lines. The boundary between badlands and Holocene alluvial surface is dotted. Stippled deposits capping badland hills on the right side of (A) are Bull Lake Fremont River gravels. The remaining gravel caps on Bull Lake alluvial surfaces are derived from caprock debris. (B) View to the east from the same location, showing the southeastern leg of North Caineville Mesa, and the Holocene alluvial surface encroaching on the badlands. The Fremont River is in the upper right corner.

River was based upon the following observations: (1) remnants of the Bull Lake alluvial surface are common in the badland headwaters and are particularly well preserved in areas remote from the river or where downcutting is inhibited by exposure of resistant sandstone along streams draining the badlands; (2) even close to the Fremont River, the highest badland divides lie just below the Bull Lake alluvial surface; (3) an extensive Holocene alluvial surface has developed close to the river, with the porportion of the area covered by alluvial surface diminishing with distance from the river; (4) channel gradients and overall relief are greatest about half way from the river to the basin divides, suggesting the headward propagation of a 'wave of dissection'; (5) the Holocene alluvial surface is underlain by a shallow veneer of sediment, indicating that the river has never scoured much below its present level. Near the Fremont River, Holocene cycles of aggradation and incision have resulted in 2-3m of sediment (Hunt, 1953), but the alluvial surface grades to near-zero thickness the contact with slopes. This pattern of landforms suggests that the alluvial surface is advancing headward, replacing badland slopes undergoing near-parallel retreat.

Modelling erosional history. A variety of histories of base level changes during the late Quaternary might have occurred, but two end members are illustrative of the range of possibilities. These are a constant rate of downcutting over the entire $71 \mathrm{ka}$ since abandonment of the Bull Lake terrace, versus a period of rapid downcutting followed by base level stability at the present river level (the sequence preferred by Howard (1970)). The drainage basin simulation model has been used to determine which best duplicates the landform assemblage described above. The initial condition for these simulations is a low relief alluvial surface generated so that the gradient is determined by solving Equation 8 for gradient, assuming that sediment yield is proportional to drainage area, giving: 


$$
{ }^{-} S=K_{\mathrm{i}} A^{-0.19}
$$

The coefficient $K_{\mathrm{i}}$ was selected so that the ratio of the average gradient of the former alluvial surface gradient to the threshold slope steepness in the modern badlands was preserved between the simulation and the field case. The initial pediment surface was created by random headward growth (Howard, 1971a) followed by systematic stream capture (Howard, 1971b) with gradients following Equation 15. The total amount of downcutting during a simulation, $Z_{\mathrm{d}}$, was fixed at a value such that the ratio of the amount of downcutting to the initial alluvial surface relief was preserved. The critical shear stress in Equation 4 was assumed to be negligible, and the value of $K_{\mathrm{t}} K_{\mathrm{z}}$ was selected to produce a drainage density such that slope profiles were well represented. Because of limitations of computer storage and simulation time, the simulated drainage density is well below that of the natural badlands. The simulations were conducted such that the lower boundary was lowered at a constant rate $E_{\mathrm{d}}$ over a time period $T_{\mathrm{d}}$ until the total incision equalled $Z_{\mathrm{d}}$. Then the base level was held constant for a time period $T_{\mathrm{s}}$. A finite duration of stable base level is required in order to develop wide alluvial surfaces, because they do not form under steady-state erosion (Howard, 1994b). The simulations were conducted for a range of values of the fractional downcutting time, $F$ :

$$
\bar{F}=\frac{T_{\mathrm{d}}}{T_{\mathrm{d}}+T_{\mathrm{s}}}
$$

and corresponding incision rates, $E_{\mathrm{d}}=Z_{\mathrm{d}} / T_{\mathrm{d}}$.

The pattern of dissection that results from incision below a low relief initial surface depends strongly upon the gradient of the initial surface. For flat to gently sloping initial surfaces, erosion progresses slowly into the interior of the dissected upland as a wave of dissection, and upland remnants remain for a considerable period. If the initial surface slopes strongly, however, a more uniform dissection by nearly parallel channels occurs. This pattern has been observed in the field (Zernitz, 1932), in experimental drainage basins (Phillips, 1987; Schumm et al., 1987), and in simulated drainage basins (Howard, 1994b). Therefore it is important that the simulations preserve the geometrical properties of the target landscape in terms of original alluvial surface gradient, threshold slope gradient, and total amount of downcutting. On the other hand, the general pattern of dissection is not strongly affected by the particular drainage pattern on the original surface as governed by the random number sequence used to generate the initial headward growth network.

A general pattern of landform evolution emerged from the simulations. In early stages during the constant rate of downcutting, incision occurs first near the base level control (the lower boundary, corresponding to the Fremont River), with high relief slopes and steep channels gradually extending further inland (Figure 8, simulated with $F=0 \cdot 16$ ). Extensive areas of nearly undissected original alluvial surface remain in headwater areas. Following cessation of downcutting, the downstream channel gradients decline until they reach a transport-limited condition. At this point an alluvial surface develops and extends headward, gradually replacing the badland slopes which undergo nearly parallel retreat (Figure 9). In later stages, most of the badlands are replaced by alluvial surface which is gradually regraded to lower gradient as the sediment yield from the retreating slopes diminishes (Figure 10). Interestingly, the simulation model suggests that the alluvial surface becomes partially dissected at this stage because of the rapidly diminishing sediment supply.

The maximum relief that develops during the rapid downcutting followed by stability is much less than the steady-state relief that would be generated by continuing the initial rate of downcutting (the equivalent steadystate topography for Figure 9 is shown in Figure 4); likewise, the drainage density in Figure 9 is higher than the steady-state case.

The stage of erosion represented by Figure 9 corresponds most closely to the present landform suite in the Caineville area, with about one-third to one-half of the badlands replaced by alluvial surface. Therefore, the condition of about one-third alluvial surface was used to define the termination time for the simulations, and the corresponding duration of stable base level $T_{\mathrm{s}}$, was noted. 


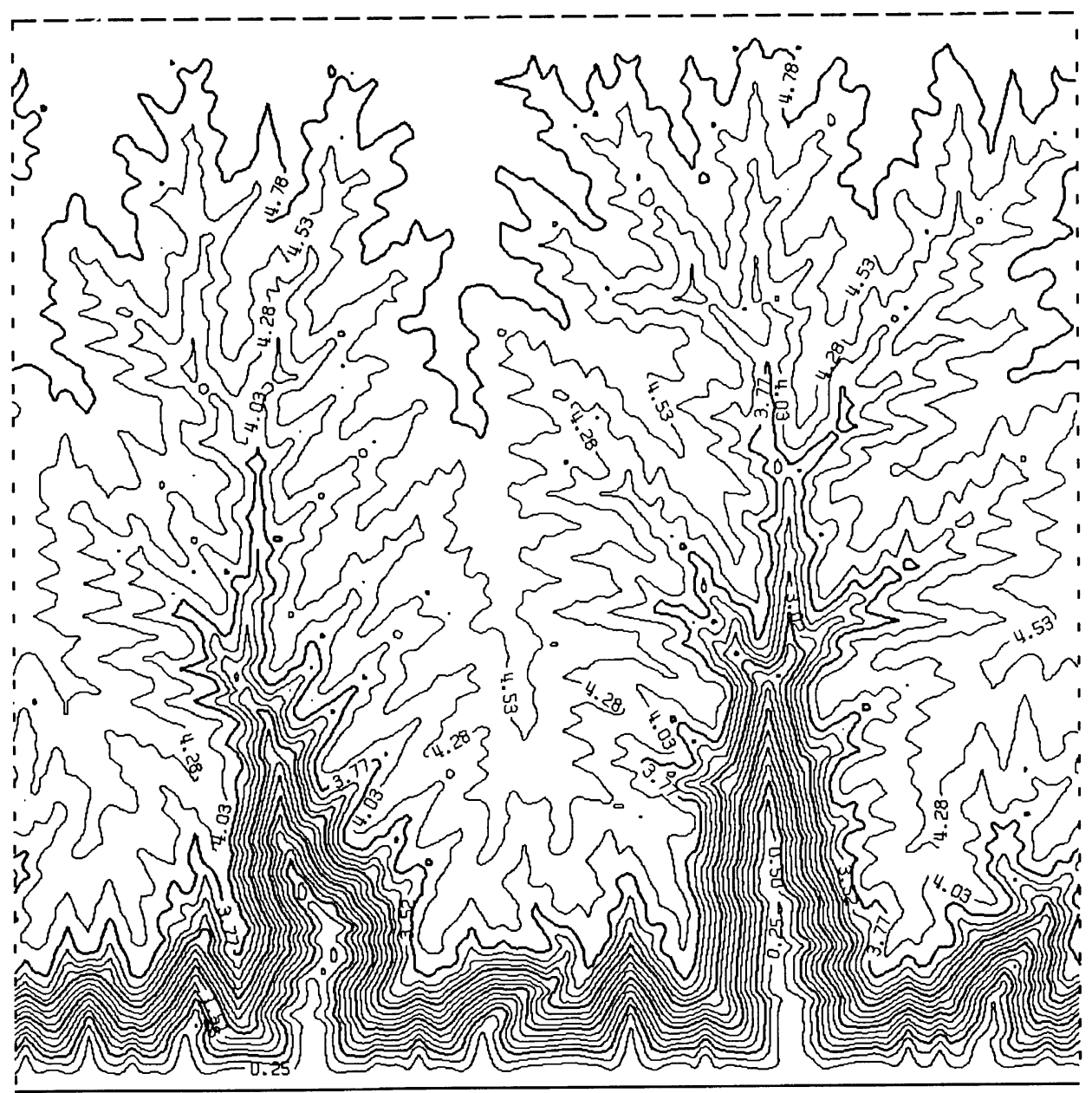

Figure 8. Early stage of dissection of an alluvial surface. Parameters are the same as for Figure 4, except $1 / \Psi_{c}=0, p=3, r=0 \cdot 5, s=0 \cdot 3, t=$ $3 \cdot 0$, and $K_{\mathrm{q}} K_{\mathrm{v}}=500$. Downcutting has been stopped after a total vertical erosion of 4.0 units (at a time $T_{\mathrm{d}}=1 \cdot 0$ ). The initial relief on the dissected alluvial surface was $1 \cdot 5$. Present time, $T=2 \cdot 36$. A small alluvial surface has begun to form adjacent to the lower boundary. Contour interval $0 \cdot 25$, maximum relief $5 \cdot 3$.

Of the various characteristics of the Caineville badland landscape listed above, the presence of a few headwater remnants of the alluvial surface and the occurrence of major divides close to the original alluvial surface elevation differ most sensitively as $F$ is varied between simulations. Figure 11 shows the ratio, $R_{\mathrm{z}}$, of the maximum relief at the end of the simulation to that of the overall relief generated by the dissection, $\mathrm{Z}_{\mathrm{d}}$, plus the maximum relative elevation on the initial undissected alluvial surface. If no erosion occurred except for the lowering of the base level, then $R_{\mathrm{z}}$ would be unity, whereas $R_{\mathrm{z}}$ tends towards zero with increasing divide erosion following the initiation of downcutting. Also shown in Figure 11 is the fractional downcutting time, $F$. Even as $F$ approaches zero (nearly instantaneous initial downcutting) the relative final relief, $R_{\mathrm{z}}$, is never more than $0 \cdot 8$ due to erosion occurring as a result of dissection of the original alluvial surface. In actuality, some of the alluvial surface remnants in the Caineville area have undergone much less than 20 per cent downcutting due to the resistance of the sandstone gravel capping. It is clear from Figure 11 that so long as the fractional downcutting time is greater than about 0.5 (incision lasting no more than 50 per cent of the post-terrace time), maximum divide elevations will be close to the level of the original alluvial surface. But if $F$ were appreciably greater than 0.5 (approaching a more constant rate of downcutting since deposition of the $62 \mathrm{~m}$ terrace), the relief on the badlands should be much smaller than the original relief, which is not observed. This supports Howard's (1970, 


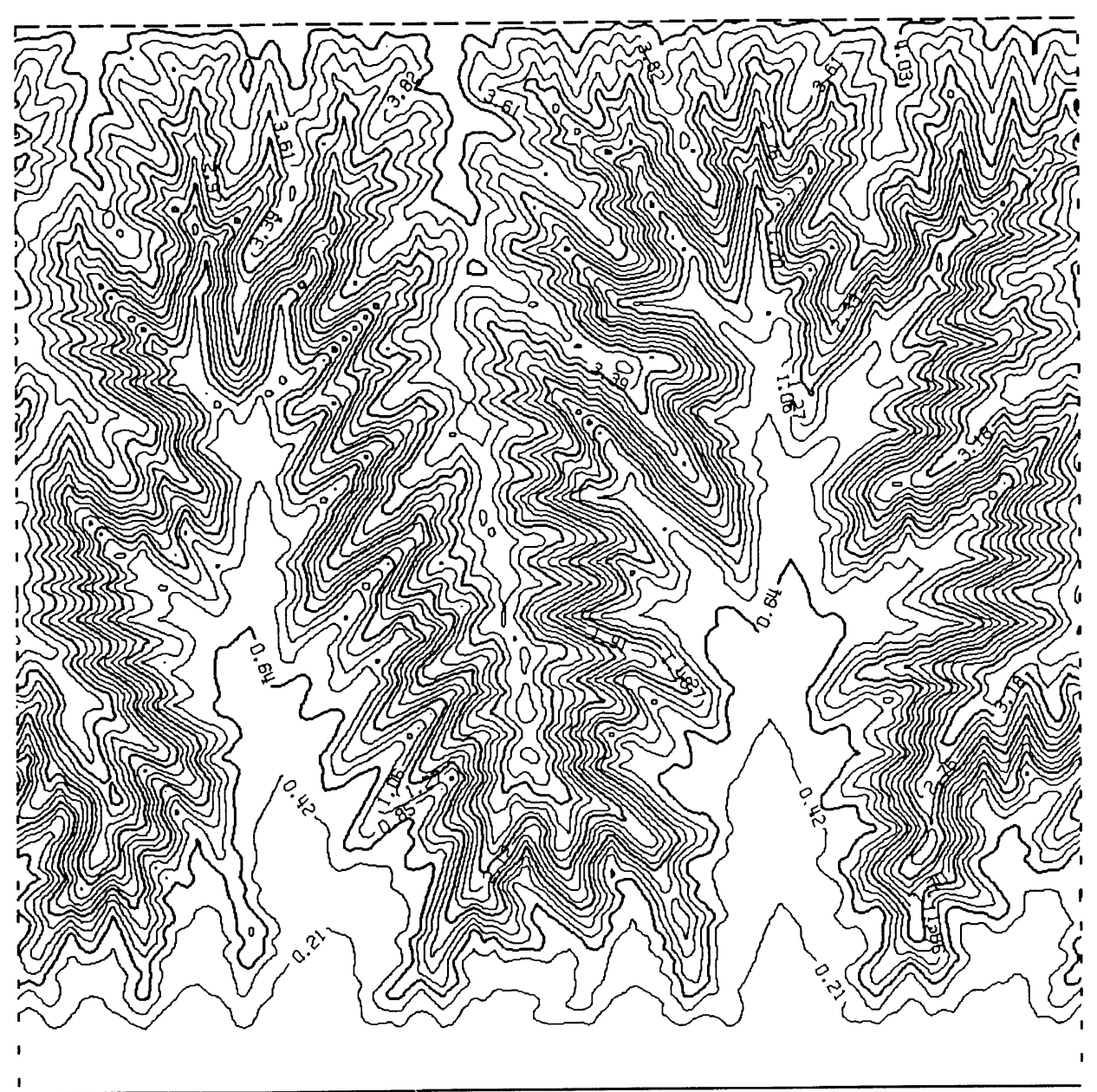

Figure 9. A later stage of evolution from Figure 8 at a total elapsed time $T=6 \cdot 24$ with a stable base level. Note headward extension of alluvial surface. Contour interval 0·21, maximum relief 4.5.

1986) conclusion that initial incision was rapid, followed by an appreciable period of time with the river close to its present elevation. It also suggests that the maximum rates of river incision and induced erosion in the badlands bordering the river exceed the long term of $700 \mathrm{~mm} \mathrm{ka}^{-1}$ by a factor of 2 to 4 . Because the pluvial alluvial surface was mantled with up to $3 \mathrm{~m}$ of sandstone gravel derived from erosion of the caprock of the Caineville Mesas, dissection of the alluvial surface may have lagged, allowing badland divides to remain near the original pediment surface level longer than the simulations (which assume uniform erodibility) imply; that is, the permissible maximum value of $F$ might be somewhat larger than the value of 0.5 inferred by the simulations.

\section{DISCUSSION}

Despite the concordance between the simulation modelling and the field interpretations of erosional history and controls on slope morphology, the mutual confirmation of model and field evidence should be considered to be preliminary. The simulation model process rate laws and model parameters have not been directly validated and calibrated by field observations. Long-term process observations would be valuable. In particular, rates of erosion in bedrock rills and channels could be measured and related to drainage area, channel gradient, and rainfall history to calibrate an erosion law of the type of Equation 4. A partial calibration of the exponents of 


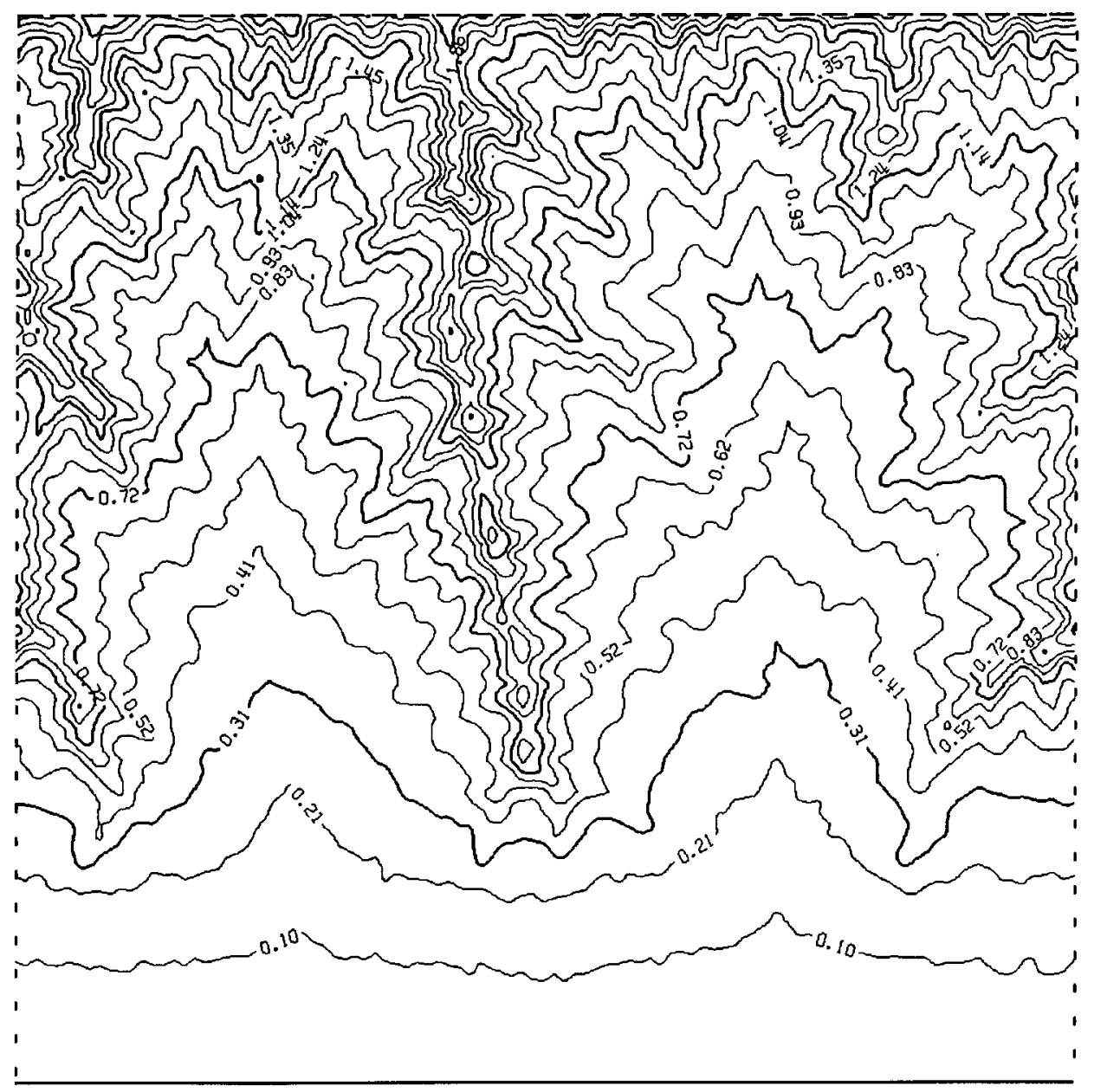

Figure 10. An advanced state of dissection at $T=12 \cdot 09$. Note the more estensive alluvial surface and lower badland relief. The alluvial surface has become partially dissected due to decrease in sediment yield from badlands. Contour interval 0.10, maximum relief 2.17.

Equation 4 could be accomplished by measuring the relationship between drainage area and channel gradient in a homogeneous high relief portion of the badlands, where approximately steady-state conditions might prevail. In addition, detailed channel surveys coupled with transient modelling of the type shown in Figures 8-10 can provide additional constraints on model parameters.

A mass-wasting rate law could also be developed by long-term detailed measurements of net surface lowering and downslope regolith displacement as a function of slope gradient, gradient divergence, contributing area and climatic parameters. A. Godfrey (personal communication) has been measuring these parameters at a few sites for more than 20 years, but the measurements are not extensive enough to characterize a process rate law. 


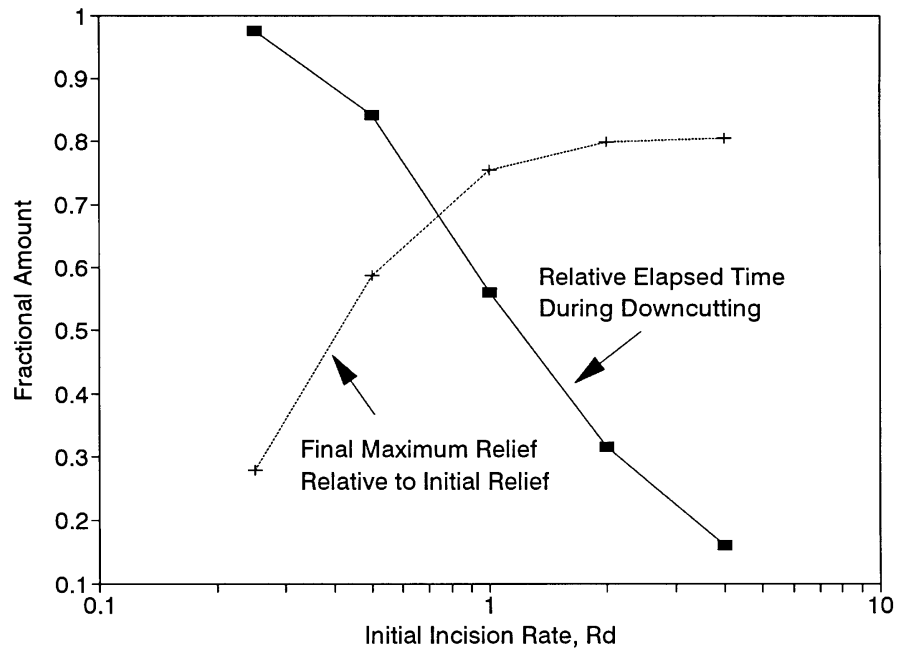

Figure 11. Relationship between relief and rate of initial incision for simulated dissection of alluvial surface. The 'relative elapsed time during downcutting' is the fractional downcutting time, $F$, of Equation 16. The simulations for various values of $F$ are stopped after about one-third of the total area becomes covered by new alluvial surface. The fractional final maximum relief, $R_{\mathrm{Z}}$, is explained in the text.

\section{REFERENCES}

Ahnert, F. 1976. 'Brief discription of a comprehensive three-dimensional process-response model of landform development', Zeitschrift fur Geomorphologie, Supplementband, 25, 29-49.

Ahnert, F. 1987. 'Process-response models of denudation at different spatial scales', Catena, 10, 31-50.

Anderson, R. S., Repka, J. L. and Dick, G. S. 1996. 'Explicit treatment of inheritance in dating depositional surfaces using in situ ${ }^{10} \mathrm{Be}$ and ${ }^{26} \mathrm{Al}$ ', Geology, 24, 47-51.

Carson, M. A. 1971. An application of the concept of threshold slopes to the Laramie Mountains, Wyoming, Institute of British Geographers Special Publication, 3, 31-47.

Carson, M. A. and Petley, D. D. 1970. 'The existence of threshold slopes in the denudation of the landscape', Transactions of the Institute of British Geographers, 49, 71-95.

Culling, W. E. H. 1960. 'Analytical theory of erosion', Journal of Geology, 68, 336-344.

Culling, W. E. H. 1963. 'Soil creep and the development of hillside slopes', Journal of Geology, 71, 127-161.

Flint, R. F. and Denny, C. S. 1958. 'Quaternary geology of Bounder Mountain, Aquarius Plateau, Utah', US Geological Survey Bulletin, 1061-D, 103-164.

Gilbert, G. K. 1880. Report on the Geology of the Henry Mountains, US Geographical and Geological Survey, Washington, DC.

Hirano, M. 1975. 'Simulation of developmental process of interfluvial slopes with reference to graded form', Journal of Geology, 83, 111123.

Howard, A. D. 1970. A Study of Process and History in Desert Landforms near the Henry Mountains, Utah, unpublished PhD dissertation, Johns Hopkins University.

Howard, A. D. 1971a. 'Simulation of stream networks by headward growth and branching', Geographical Analysis, 3, $29-50$.

Howard, A. D. 1971b. 'Simulation model of stream capture', Bulletin of the Geological Society of America, 82, 1355-1376.

Howard, D. D. 1986. 'Quaternary landform evolution of the Dirty Devil River system, Utah' (abs.), Geological Society of America Abstracts with Program, 641.

Howard, A. D. 1994a. 'Badlands', in Abrahams, A. D. and Parsons, A. J. (Eds), Geomorphology of Desert Environments, Chapman \& Hall, London, 213-242.

Howard, A. D. 1994b. 'A detachment-limited model of drainage basin evolution', Water Resources Research, 30, $2261-2285$.

Howard, A. D. and Selby, M. J. 1994. 'Rock slopes', in Abrahams, A. D. and Parsons, A. J. (Eds), Geomorphology of Desert Environments, Chapman \& Hall, London, 123-172.

Hunt, C. B. 1953. Geology and Geography of the Henry Mountains Region, US Geological Survey Professional Paper 228.

Kirkby, M. J. 1971. Hillslope process-response models based on the continuity equation, Special Publication, Institute of British Geographers, 3, 15-30.

Kirkby, M. J. 1980. 'The stream head as a significant geomorphic threshold', in Coates, D. R. and Vitek, J. D. (Eds), Thresholds in Geomorphology, George Allen \& Unwin, London, 53-73.

Kirkby, M. J. 1984. 'Modelling cliff development in south wales. Savigear re-viewed', Zeitschrift fur Geomorphologie, 28, $405-426$.

Kirkby, M. J. 1985. 'A model for the evolution of regolith-mantled slopes', in Woldenberg, M. J. (Ed.), Models in Geomorphology, Allen \& Unwin, Boston, 213-237.

Kirkby, M. J. 1986. 'A two-dimensional simulation model for slope and stream evolution', in Abrahams, A. D. (Ed.), Hillslope Processes, Allen \& Unwin, Boston, 203-222. 
Kirkby, M. J. 1994. 'Thresholds and instability in stream head hollows: a model of magnitude and frequency for wash', in Kirkby, M. J. (Ed.), Process Models and Theoretical Geomorphology, John Wiley \& Sons, Chichester, 295-314.

Laronne, J. B. 1981. 'Dissolution kinetics of Mancos shale-associated alluvium', Earth Surface Processes and Landforms, 6, 541-552.

Laronne, J. B. 1982. 'Sediment and solute yield from Mancos Shale hillslopes, Colorado and Utah', in Bryan R. and Yair, A. (Eds), Badland Geomorphology and Piping, Geo Books, Norwich, 181-192.

Morrison, R. B. 1991. 'Introduction', in Morrison R. B. (Ed.), Quaternary Non Glacial Geology: Conterminous U.S., Geological Society of America, Geology of North America, K-2, 1-12.

Moseley, M. P. 1973. 'Rainsplash and the convexity of badland divides', Zeitschrift fur Geomorphologie, Supplementband, 18, 10-25. Phillips, L. F. 1987. 'Effect of regional slope on drainage networks', Geology, 15, 498-521.

Schumm, S. A. 1956. 'Evolution of drainage systems and slopes in badlands at Perth Amboy, New Jersey', Bulletin of the Geological Society of America, 67, 597-646.

Schumm, S. A., Mosley, M. P. and Weaver, W. E. 1987. Experimental Fluvial Geomorphology, John Wiley \& Sons, New York, 413 pp.

Smith, J. F. Jr, Huff, L. C., Hinrichs, E. and Luedke, R. G. 1963. Geology of the Capital Reef area, Wayne and Garfield Counties, Utah, US Geological Survey Professional Paper, 363, 102 pp.

Willgoose, G., Bras, R. L. and Rodriguez-Iturbe, I. 1991a. 'A coupled channel network growth and hillslope evolution model, 1, Theory', Water Resources Research, 27, 1671-1684.

Willgoose, G., Bras, R. L. and Rodriguez-Iturbe, I. 1991b. 'A coupled channel networth growth and hillslope evolution model, 2, Nondimensionalization and applications', Water Resources Research, 27, 1685-1696.

Zernitz, E. R. 1932. 'Drainage patterns and their significance', Journal of Geology, 40, 498-521. 